\title{
ANALISA ENVIRONMENTAL COST PADA PERUSAHAAN NON-KEUANGAN YANG TERDAFTAR DI BURSA EFEK INDONESIA PERIODE 2011, 2012 DAN 2013
}

\author{
Kartika Dewi \\ Accounting and Finance Department, Faculty of Economic and Communication, BINUS University \\ Jln. K.H. Syahdan No.9, Palmerah, Jakarta Barat 11480 \\ kdewi@binus.edu
}

\begin{abstract}
ABSTRAK
Environmental damage due to over-exploitation by employers without thinking about environmental improvements result in long-term environmental damage. Allocation of environmental costs, making high expenses on companies that ultimately will reduce net income. This study will examine companies that have great potential to damage the environment, but the company is willing to make the allocation of environmental costs in its income statement, and the company also wants to follow the PROPER program created by the Ministry of Environment for the period 2011 to 2013. The research was conducted using secondary data in www.idx.co.id and www.proper.menlh.go.id. Financial Statements of the company that made the sample examined by checking whether there is environmental damage costs are allocated and check the results of PROPER (Program Performance Rating). This study will determine whether the company identifying, recognizing, measuring and presenting the cost of environmental damage in the Financial Statements. Results obtained from secondary data is that many companies have yet to identify, acknowledge, measure and present the cost of the destruction of nature in the financial statement, the company may have a cost allocation but still use the Incidental Charges account, so that when the pages are checked through www.idx.co.id charge is not visible. It is expected that in the future the company create its own environmental cost allocation account so that it can be easily identified by users of Financial Statements.
\end{abstract}

Keywords: environmental costs, environmental degrades, PROPER, financial ftatements

\begin{abstract}
ABSTRAK
Kerusakan lingkungan hidup akibat eksploitasi besar-besaran oleh pengusaha tanpa memikirkan perbaikan lingkungan hidup mengakibatkan kerusakan lingkungan hidup jangka panjang. Pengalokasian environmental cost ini, membuat expenses tinggi pada perusahaan yang akhirnya akan mengurangi net income.Penelitian ini akan meneliti perusahaan yang memiliki potensi besar untuk merusak lingkungan hidup, tetapi perusahaan tersebut mau membuat alokasi biaya lingkungan di Income Statement-nya dan perusahaan tersebut juga mau mengikuti program PROPER yang dibuat oleh Kementerian Lingkungan Hidup selama kurun waktu 2011 hingga 2013. Penelitian dilakukan dengan menggunakan data sekunder yang ada di www.idx.co.id dan www.proper.menlh.go.id. Laporan Keuangan perusahaan yang dijadikan sample diperiksa dengan mengecek apakah ada biaya kerusakan lingkungan hidup yang dialokasikan dan memeriksa hasil dari PROPER (Program Penilaian Peringkat Kinerja Perusahaan). Penelitian ini akan mengetahui apakah perusahaan mengidentifikasi, mengakui,mengukur dan menyajikan biaya kerusakan alam didalam Laporan Keuangan. Hasil yang diperoleh dari data sekunder adalah banyak perusahaan belum mengidentifikasi, mengakui, mengukur dan menyajikan biaya kerusakan alam dalam Laporan Keuangan, perusahaan mungkin mempunyai alokasi biaya tetapi masih menggunakan akun Biaya Tak Terduga, sehingga pada saat ini dicek melalui laman www.idx.co.id biaya ini tidak terlihat. Diharapkan dimasa yang akan datang perusahaan membuat alokasi akun biaya lingkungan tersendiri sehinga dapat mudah diidentifikasi oleh pengguna Laporan Keuangan.
\end{abstract}

Kata kunci: biaya lingkungan hidup, kerusakan alam, PROPER, financial statements 


\section{PENDAHULUAN}

Sebelum tahun 2000 misi dan visi perusahaan adalah menciptakan laba sebanyak-banyaknya tanpa memikirkan dampak negatif yang akan terjadi sepanjang perusahaan menghasilkan laba sepanjang tahun. Pemenuhan laba ini hanya memenuhi keinginan shareholders atau pemilik. Setelah tahun 2000 perusahaan mulai memikirkan pihak-pihak shareholders/pihak external perusahaan yang tidak mempunyai kepentingan langsung dengan perusahaan tetapi ikut menikmati dampak dari bisnis yang dikelola. Selama ini menjaga lingkungan hidup tetap terpelihara, rapi, dan lestari belum menjadi perhatian utama bagi perusahaan di Indonesia, terutama perusahaan yang berbisnis dengan Lingkungan Hidup. Pemerintah Indonesia telah mencanangkan program Pelestarian Lingkungan Hidup untuk hutan, sungai dan tanah supaya alam tetap terpelihara dan tidak kehilangan potensi. Berkaitan dengan pelaporan kegiatan perusahaan yang berhubungan dengan eksploitasi alam maka muncul sub-ilmu baru dalam akuntansi yaitu Akuntansi Lingkungan. Sebagai sub-ilmu baru Akuntansi Lingkungan mensyaratkan agar perusahaan membuat pelaporan biaya yang berkaitan dengan Lingkungan Alam di Laporan Keuangan yang disajikan ke pihak eksternal dan internal.

Limbah yang dihasilkan dari proses produksi biasanya dibuang begitu saja di sungai, tanah dan Tempat Pembuangan Akhir (TPA). Limbah-limbah yang dibuang begitu saja tanpa diolah lagi sangat berbahaya bagi alam dan makhluk hidup yang lain. Limbah ini bisa berupa limbah padat, cair, gas dan polusi suara. Kerusakan alam yang ditimbulkan menjadi lingkaran setan yang tak berakhir. Kebisingan yang didengar terus menerus membuat kerusakan indera pendengar dan depresi jiwa. Pada umumnya perusahaan telah membuat akun biaya pengolahan limbah yang dilakukan tetapi pelaporannya masih tergabung dengan akun yang lain. Pelaporan biaya pengolahan limbah seharusnya berdiri sendiri sebagai akun "Pengolahan Limbah" atau "Pelestarian Lingkungan" dan diharapkan para pembaca laporan Keuangan langsung dapat mengetahui besaran biaya pengolahan limbah ataupun biaya restorasi alam yang dibuat oleh perusahaan.

Pelaporan biaya pengolahan yang baik dan benar merupakan pertanggung jawaban sosial yang baik dari perusahaan. Perusahaan di era teknologi ini tidak hanya berkonsentrasi pada perolehan laba saja tetapi lebih memperhatikan lingkungan alam dan masyarakat sekitar perusahaan, termasuk hal-hal yang dapat diberikan kembali ke masyarakat. Dalam menjalankan operasional sehari-hari, perusahaan pasti berorientasi pada laba semaksimal mungkin. Memaksimalkan laba berarti mengurangi biaya. Memisahkan biaya pengolahan limbah berarti menambah biaya dan hal ini menjadi tidak berbanding lurus dengan peningkatan laba. Pemisahaan biaya pengolahan limbah ini memerlukan alokasi biaya tersendiri. Tetapi pelaporan biaya terkait aktifitas lingkungan merupakan hal wajib diera baru ini dan menyebabkan munculnya Akuntansi Lingkungan.

Akuntansi Lingkungan merupakan ilmu akuntansi baru yang berkaitan dengan hal-hal sosial. Tidak mau tertinggal dengan negara lain dalam hal Akuntansi Lingkungan maka Kementerian Lingkungan Hidup (KLH) mengadakan PROPER (Program Penilaian Peringkat Kinerja Perusahaan dalam Pengelolaan Lingkungan Hidup) pada tahun 2002. Berdasarkan uraian di atas mengenai Akuntansi Lingkungan maka penelitian akan berfokus pada perusahaan non keuangan yang dalam kegiatan operasinya banyak membuang limbah atau menggunakan bahan baku dari alam. Penelitian ini dilakukan dengan melihat Laporan Keuangan audited perusahaan tersebut yang terdaftar di Bursa Efek Indonesia dan yang mengikuti program PROPER.

Laporan Keuangan yang diteliti disajikan melalui situs laman www.idx.co.id. Adapun permasalahan yang ingin diteliti adalah adanya pemisahan biaya akuntansi lingkungan di Laporan Keuangan yang disajikan dan adanya catatan-catatan akuntansi mengenai kebijaksanaan lingkungan yang ditempuh sebagai contoh tanggung jawab sosial dari perusahaan ke masyarakat misalnya melalui program CSR (Corporate Sosial Responsibility) atau penanaman pohon diarea perusahaan. 
Penelitian sebelumnya dilakukan oleh Bozidar dan Ivanizevic (2013) dengan judul Assessment of the Most Significant Impacts of Environment on the Changes in Company Cost Structure mengatakan bahwa perusahan harus memisahkan biaya environment dalam cost structure-nya. Sedangkan dalam tulisan Akuntansi Kejepangan (19 Januari 2013) mengatakan Akuntansi Lingkungan sangat diperlukan oleh perusahaan dan dilakukan pemisahan biaya yang berkaitan dengan proses pengrusakan lingkungan karena dalam proses operasional perusahaan berpotensi merusak alam.

Perusahaan adalah bentuk organisasi yang melakukan aktivitas dengan menggunakan sumber daya yang tersedia untuk mencapai tujuan yang telah ditetapkan. Jenis perusahaan terbagi menjadi tiga yaitu perusahaan jasa, perusahaan dagang dan pabrikan. Perusahaan jasa adalah perusahaan yang memberikan jasa kepada pelanggan misalnya Rumah Sakit, Hotel, Kantor Akuntan, Kantor Pengacara, Salon. Perusahaan dagang adalah perusahaan yang membeli Finish Goods dari pabrikan. Pabrikan adalah perusahaan yang mengolah RawMaterials menjadi Finish Goods. Raw Material yang digunakan bisa diperoleh dari alam seperti batubara, emas, kayu, air ataupun non alam.

Posisi perusahaan sebagai penyedia lapangan pekerjaan bagi masyarakat sekitar menjadi sangat vital dan sifatnya legitimasi dalam arti mungkin perusahaan menggunakan sumber daya alam sewenang-wenang dan membuang limbahnya sesuka hati padahal limbah yang dibuang sangat berbahaya, tidak baik untuk mahluk hidup disekitarnya tetapi perbuatan perusahaan tersebut dibiarkan saja karena perhatian masyarakat sekitar kurang baik, pemahaman akan pentingnya lingkungan yang baik belum memadai. Bila dibiarkan terus menerus maka akan timbul dampak negatifnya. Dampak negatif ini biasanya polusi suara dari mesin, limbah produksi dan kesenjangan hubungan. Dampak negatif ini dikenal dengan istilah Externalities. Dampak dari Externalities harus ditekan seminimal mungkin karena masyarakat sekitar ingin adanya dampak positif dari kehadiran suatu pabrik terutama penyediaan lapangan pekerjaan. Bukan malah dampak negatif yang terjadi seperti rusaknya lingkungan sekitar pabrik. Dari externalities tersebut maka muncullah pemikiran mengenai Akuntansi Lingkungan. Dalam Ilmu Akuntansi Lingkungan terdapat pengukuran, penyajian, pengungkapan dan pelaporan externalities.

Ilmu Akuntansi Lingkungan selangkah lebih maju ketimbang akuntansi konvensional, tidak hanya melaporkan posisi keuangan ke pembacanya tetapi juga hubungan antara perusahaan dan lingkungan sekitar di mana perusahaan beroperasi. Pada mulanya akuntansi adalah ilmu yang memproses data keuangan saja, sesuai dengan terminologi dari Weygant, Kimmel, Kieso dalam bukunya Financial Accounting, IFRS Edition halaman 4. Accounting identifies, records and communicates the economic events of an organization to interested users. Akuntansi pada awalnya hanya mengidentifikasi transaksi yang perlu dicatat dan economic events yang dicatat berbentuk jurnal tersebut di-summary-kan kemudian dikomunikasikan ke pembacanya. Akhirnya ilmu akuntansi merambah ke bidang sosial dalam bentuk pertanggung jawaban perusahaan terhadap lingkungan. Tujuan dari Akuntansi Lingkungan adalah perusahaan patuh dengan peraturan yang dikeluarkan pemerintah dan dicari cara untuk meminimalkan dampak negatif dari externalities tersebut.

Perusahaan tidak hanya mengambil manfaat dari alam lingkungan tetapi juga melakukan konservasi lingkungan yang berkelanjutan. Bila konservasi lingkungan tidak dibuat maka alam akan rusak, misalnya bencana banjir, pemanasan global karena efek rumah kaca, meluasnya gurun, pergeseran cuaca seperti yang dialami beberapa tahun lalu khususnya di Indonesia, di saat musim panas mendapat hujan yang cukup deras seperti di tahun 2013. Limbah produksi sebagai hasil akhir, sisa dari hasil operasional selalu mengandung zat-zat berbahaya bagi makhuk hidup. Contohnya adalah Rumah Sakit, sampah yang dihasilkan Rumah Sakit berupa sampah bekas perban, bekas potongan tubuh, jarum, botol-botol obat, makanan, muntahan pasien dan kamar mandi. Zat-zat yang dibuang begitu saja tanpa diolah terlebih dahulu sangat berbahaya bagi lingkungan alam sekitar Rumah Sakit tersebut. Contoh lain adalah Hak Pengolahan Hutan (HPH) melakukan penebangan pohon sewenang-wenang tanpa menanam kembali pohon-pohon dihutan, akibatnya timbul bencana banjir dan rusaknya rantai makanan binatang pemakan daging (carnivore). 
Industri Pertambangan pun banyak berkontribusi dalam perusakan lingkungan sekitar dan air resapan sekitar tambang banyak yang tercemar B3 (Bahan Berbahaya dan Beracun). Contoh pengeboran minyak yang terkenal adalah lumpur Lapindo di Sidoharjo. Kesalahan terletak di perusahaan karena kurang perencanaan mengakibatkan pengerusakan alam dan hilangnya nyawa manusia dan binatang serta kerugian material dan moril masyarakat sekitar. Sungguh tragis kejadian lumpur Lapindo dan hingga saat penulisan ini berlangsung kasus Lapindo tidak ada kejelasan mengenai ganti rugi secara material bagi penduduk yang kehilangan rumahnya. Kejadian Lapindo ini memang diketahui oleh khalayak luar karena publikasi media terus menerus tetapi perusahaan yang tidak terekspos media tidak diketahui kegiatan operasinya. Salah satu cara meneliti perusahaan telah menerapkan akuntansi lingkungan yang baik adalah dengan melihat Laporan Keuangan Audited yang dipublished ke masyarakat dan situs Menteri Lingkungan Hidup atas keikutsertaan perusahaan dalam program PROPER.

\section{Sejarah Singkat Munculnya Akuntansi Lingkungan}

Konsep akuntansi lingkungan dicetuskan di Eropa sekitar tahun 1970 karena tekanan dari kalangan non-pemerintah yang menginginkan industri memperhatikan lingkungan yang dikelola dengan baik bukan hanya mengambil Sumber Daya Alam saja. Kemudian ditahun 1990 Komite Standar Akuntansi Internasional (The International Accounting Standards Committee-IASC) yang bertugas mengembangkan prinsip-prinsip akuntansi internasional di mana termasuk akuntansi lingkungan dan audit hak asasi manusia kemudian standar untuk industri juga semakin berkembang dan asosiasi auditor profesional seperti the American Institute of Certified Public Auditor (AICPA) mengeluarkan prinsip-prinsip universal tentang environmental audits.

Untuk kawasan Asia Pasific, Perusahaan Jepang Canon memulai akuntansi lingkungan pada tahun 1983 dan diikuti oleh perusahaan lainnya dan sebagian besar perusahaan di Jepang memulai menerapkan akuntansi lingkungan pada tahun 1990. Hal ini berkaitan dengan keterbukaan perusahaan untuk mengungkapkan informasi lingkungan sebagai dampak dari hasil kegiatan industri perusahaan. Peningkatan penggunaan akuntansi lingkungan di Jepang disebabkan oleh diterbitkannya pedoman akuntansi lingkungan (environmental accounting guidelines) oleh Menteri Lingkungan Hidup Jepang tahun 1999 karena pada waktu itu Menteri Lingkungan Hidup Jepang menduduki salah satu jabatan di anggota tim United Nations Division for Sustainable Development (UNDSD) dan juga anggota Environmental Management Accounting Network Asia Pasific (EMANAP). EMANAP adalah organisasi yang didirikan pada bulan September 2001 yang terdiri dari praktisi dan peneliti dari 14 negara diAsia Pasifik yang bertujuan untuk memperkenalkan dan menyebarluaskan penggunaan metode akuntansi managemen lingkungan serta memberikan sumbangan,dukungan pada pembangunan berkelanjutan diAsia Pasifik. Pada tahun 2005 perusahaan Jepang diwajibkan untuk menerapkan akuntansi lingkungan. Hal ini menjadikan posisi akuntansi lingkungan sejajar dengan akuntansi keuangan.

\section{Akuntansi Lingkungan}

Menurut Badan Perlindungan Lingkungan Amerika Serikat atau United States Environment Protection Agency (US EPA) Akuntansi Lingkungan adalah:

"Fungsi penting akuntansi lingkungan adalah untuk menyajikan biaya-biaya lingkungan bagi para stakeholders perusahaan, yang mampu mendorong pengidentifikasian cara-cara mengurangi atau menghindari biaya-biaya ketika pada waktu yang bersamaan, perusahaan sedang memperbaiki kualitas lingkungan”. 


\section{Partisipasi Indonesia Untuk Akuntansi Lingkungan}

Program-program lingkungan diIndonesia dirancang untuk memenuhi kebutuhan masa kini dan dikembangkan lagi di masa depan serta mengikuti perubahan kondisi Nasional dan Internasional. Semua program dikeluarkan oleh Bapedal (Badan Pengendalian Dampak Lingkungan). Bapedal adalah Lembaga dibawah naungan Kementerian Lingkungan Hidup. Program Bapedal terdiri atas: (1) Analisis Mengenai Dampak Lingkungan (AMDAL). (2) Program Kali Bersih (PROKASIH). (3) Pengolahan Limbah Bahan Berbahaya dan Beracun (B3). (4) ADIPURA. (5) Produksi Bersih (PRODUKSIH). (6) Program Penilaian Kinerja Lingkungan (PROPER). (7) Pengembangan Audit Lingkungan. (8) Pengendalian Dampak Skala Kecil. (9) Pengendalian Kerusakan Lingkungan. (10) Pengendalian Pencemaran Kerja. (11) Pengendalian Pencemaran Laut dan Pesisir. (12) Pembinaan Laboratrium Lingkungan. (13) Pengembangan Sumber Daya Manusia dan Bidang Pengendalian Dampak Lingkungan. (14) Ekolabel. (15) Sistem Informasi Bapedal (Badan Pengendalian Dampak Lingkungan)

\section{Program PROPER}

Pada awal 1995 Bapedal membuat program PROKASIH (Program Kali Bersih) yang merupakan cikal bakal PROPER. Pada saat itu perusahaan yang terlibat dalam program PROKASIH hanya perusahaan yang ada di sepanjang kali atau sungai, program tersebut hanya menyangkut pencemaran air yang dilakukan perusahaan yang berada di sepanjang kali atau sungai sehingga dengan berkembangnya waktu dirasa kurang tepat sasaran selain banyaknya perusahaan lain yang tidak di sepanjang sungai tetapi limbahnya merusak alam lingkungan sehingga muncul PROPER yang dirasa lebih baik.

PROPER adalah program yang dibuat oleh Kementrian Lingkungan Hidup untuk menata perusahaan dalam pengelolaan lingkungan hidup melalui instrumen informasi. Dasar hukum PROPER adalah Keputusan Menteri Negara Lingkungan Hidup No 127/MENLH/2002 tentang Program Penilaian Peringkat Kinerja Perusahaan dalam Pengelolaan Lingkungan (PROPER). PROPER juga merupakan perwujudan transparasi, demokrasi dalam pengelolaan lingkungan alam di Indonesia sehingga tercapai Good Governance di tiap perusahaan yang ikut serta dalam program PROPER.

Penilaian atas kinerja PROPER menggunakan persyaratan yang telah ditetapkan dalam perundang-undangan dan kegiatan pengelolaan lingkungan yang belum menjadi persyaratan penaatan (beyond compliance). Penilaian difokuskan pada pengendalian pencemaran air, udara, B3 dan AMDAL. Untuk sektor penambangan belum diatur mengenai pengrusakan lahan. Sedangankan untuk beyond compliance terdiri dari Sistem Management Lingkungan, konservasi dan Corporate Sosial Responsibility (CSR). Penilaian kinerja PROPER menggunakan warna sebagai nilainya yang terbagi menjadi warna emas sebagai nilai tertinggi kemudian disusul warna hijau, biru, merah dan hitam sebagai nilai terburuk. Adapun kriteria tiap warna adalah sebagai berikut: (1) Emas bila perusahaan telah menunjukkan konsistensi atas environmental excellency atas produksi barang atau jasa, melakukan bisnisnya dengan penuh etika dan bertanggung jawab kepada masyarakat. (2) Hijau bila perusahaan telah melakukan pengelolaan lingkungan lebih dari yang telah dipersyaratkan (beyond compliance) melalui pelaksanaan sistem pengelolaan lingkungan, pemanfaatan sumber daya secara efisien melalui upaya 4R (Reduce, Reuse, Recyle, Recovery) dan melakukan Corporate Social Responsibility dengan baik. (3) Biru bila perusahaan telah melakukan pengelolaan lingkungan yang dipersyaratkan sesuai dengan ketentuan peraturan perundang-undangan yang berlaku. (4) Merah bila perusahaan belum melakukan pengelolaan lingkungan yang dipersyaratkan sesuai dengan ketentuan peraturan perundang-undangan yang berlaku dan dikenakan sanksi administrasi. (5) Hitam bila perusahaan dengan sengaja melakukan kegiatan merusak alam, melakukan pencemaran dan pelanggaran terhadapketentuan peraturanperundang-undangan yang berlaku dan tidak melaksanakan sanksi administratif. 


\section{Peserta PROPER}

Peserta PROPER adalah 1.002 perusahaan di tahun 2011 dan meningkat menjadi 1.317 perusahaan di tahun 2012, dan tahun 2013 menjadi 1.812 perusahaan. Industri yang paling banyak adalah sawit, eksplorasi, migas, textile, rumah sakit, hotel dan makanan dan minuman. Tingkat ketaatan pun meningkat dari 66\% ditahun 2011 menjadi 69\% ditahun 2012 dan menjadi 65\% ditahun 2013.Peserta yang mendapat peringkat hitam sebanyak 49 perusahaan ditahun 2011,79 perusahaan ditahun 2012 dan 17 perusahaan ditahun 2013 terbanyak didapat dari industri hotel, pengolahan ikan, rumahsakit, kayulapis, tambang, makanan minuman dan textile. Peserta PROPER yang mendapatkan peringkat hitam karena tidak taat dalam pengelolaan B3. Industri yang taat aturan PROPER sebagian besar berasal dari industri migas, energi, kertas, gula, pupuk dan ban.

\section{Pencemaran Lingkungan}

Pencemaran lingkungan adalah adanya polutan berbahaya dalam tubuh makhluk hidup,zat, dan energi dimana keadaan tersebut menurunkan kualitas hidup dan menyebabkan lingkungan alam tidak dapat berfungsi sebagai penunjang kehidupan selanjutnya. Ada tiga hal penting dalam pencemaran lingkungan: (1) Unsur yang masuk atau dimasukkan kedalam lingkungan. (2) Kualitas lingkungan menurun. (3) Peruntukan atau fungsi lingkungan berubah

Pencemaran lingkungan terbagi menjadi tiga jenis pemcemaran yaitu: (1) Pencemaran air - air yang tercemar adalah air yang tidak bisa digunakan atau kurang layak digunakan untuk tujuan yang dimaksud sebagaimana keadaan air yang alami/wajar. Adapun ciri air yang terkena limbah pencemaran adalah bau, berwarna, mempunyai rasa, ada endapan, ada mikroorganisme, suhu air meningkat, $\mathrm{pH}$ berubah. Air bersih mempunyai ciri-ciri bersih, bening, tidak berbau dan suhu kamar. Air yang telah tercemar tidak dapat digunakan untuk keperluan Rumah Tangga, irigasi,perikanan yang dibudidayakan dan oleh perusahaan yang industrinya banyak menggunakan air bersih. Penggunaan air tercemar dapat mengakibatkan kulit gatal dan ikan mati didalam air. (2) Pencemaran udara, substansi masuk ke dalam udara sehingga mengganggu kesehatan manusia dan makhluk hidup lainnya, udara menjadi kotor dan dapat mengakibatkan gangguan kulit, sesak napas dan gangguan bagian dalam tubuh secara langsung atau tidak langsung dan berefek pada kesehatan dalam jangka pendek dan panjang. (3) Pencemaran tanah, berubahnya unsur zat hara yang ada di tanah, perubahan fisik tanah sehingga tanah mengalami penurunan penggunaannya dan harus diolah dulu sebelum digunakan. Cacing tanah yang berfungsi sebagai penggembur tanah juga mati. Limbah sisa industri yang bersifat B3 (Bahan Berbahaya dan Beracun) biasanya mengendap di dalam tanah dan benar-benar mengurangi kualitas hidup makhluk hidup terutama manusia. Jenis B3 yang mengendap di dalam tanah adalah logam berat, arsenat, timah, krom dan karbondioksida. Logam-logam ini pencetus kanker di tubuh manusia.

Salah satu cara untuk pengelolaan lingkungan alam adalah dengan membuat biaya pencemaran baik dari air, udara dan tanah dan besaran biaya tersebut diinformasikan sehingga sejumlah biaya tersebut dapat dialokasikan pada tiap periode akuntansi dan dibebankan sebagai period cost. Berikut ini adalah beberapa industri penyumbang limbah B3 yang berpotensi merusak alam lingkungan dimasa yang akan datang. Diantaranya adalah hotel, rumah sakit, pertambangan, pabrikan barang konsumsi,makanan dan minuman dan industri kimia

Hotel adalah industri yang memberikan pelayanan kepada pelanggan dan seluruh bagian di hotel menghasilkan sampah basah dan kering. Sampah basah berasal dari dapur, restaurant. Sedangkan sampah kering berasal dari kertas, plastik, kain dan lain-lain. Penanganan sampah hotel harus segera karena sampah basah yang berasal dari makanan dapat terurai dengan cepat dan menghasilkan bau yang menyegat dan menyebabkan serangga dan binatang mengerat datang ke hotel. 
Rumah Sakit adalah jenis perusahaan berpotensi besar sebagai penghasil limbah B3 sehingga Rumah Sakit harus mengelola limbah sebelum dibuang ke air atau tanah. Salah satu pengelolaan air yang lazim digunakan adalah IPAL (Instalasi Pengolahan Air Limbah). Dalam IPAL air disaring berlapis-lapis hingga tujuh kali penyaringan sehingga air layak untuk dikonsumsi kembali. Indikator air sudah layak untuk dikonsumsi adalah menempatkan ikan di kolam penyaringan terakhir. Dari hasil penelitian yang dilakukan melalui internet, tidak ada Rumah Sakit yang go-public per 31 Desember 2013. Sehingga, tidak diperoleh data Laporan Keuangan yang di Audit yang terlisting di Bursa Efek Indonesia.

Industri Pertambangan banyak menyumbang pengerusakan lingkungan alam karena banyaknya pertambangan illegal yang tidak memiliki ijin pertambangan, melakukan penambangan diluar area yang diperbolehkan, perusahaan tidak memiliki dokumen AMDAL. Kerusakan alam yang disebabkan oleh pertambangan adalah erosi, kerusakan hutan, kerusakan mangrove, tipisnya lapisan tanah, pencemaran air tanah, banjir. Sampai saat ini belum ada peraturan pemerintah mengenai audit lingkungan. Dengan adanya audit lingkungan maka perizinan pertambangan dapat ditekan.

Industri Makanan dan Minuman merupakan penghasil limbah lingkungan alam yang berasal dari sisa-sisa hasil produksi dan dapat membusuk dengan cepat. Mikroba dapat berkembang di tanah, udara dan air dan menyebabkan penyakit pada manusia dan binatang. Ada juga sisa limbah berupa sisa soda kue yang menghasilkan gas reaktif dan mudah terbakar begitu terkena oksigen. Industri kimia merupakan salah satu penghasil limbah B3 karena industri kimia menggunakan bahan baku, bahan penolong B3.B3 perlu disimpan dengan baik agar tidak tercecer, tidak terbakar dan meledak. Industri kimia harus melakukan waste prevention,waste elimination, waste reduction dengan baik dan benar.

\section{METODE}

Metode yang digunakan dalam penelitian adalah metode kualitatif deskriptif yaitu dengan cara mengumpulkan, menyajikan dan menganalisa data asli dan tidak merubah data asli sehingga dapat dipertanggungjawabkan keabsahan data tersebut. Data yang digunakan adalah data sekunder. Penelitian dilakukan dengan melihat Laporan Keuangan perusahaan non-keuangan audited yang terdaftar di Bursa Efek Jakarta dari tahun 2011 hingga 2013. Melalui situs laman www.idx.co.id yang merupakan situs resmi dari Bursa Efek Indonesia. Selain itu perusahaan juga mengikuti program PROPER melalui situs laman www.menlh.com yang merupakan situs resmi dari Kementerian Lingkungan Hidup Republik Indonesia. Sampel diambil sebanyak sembilan perusahaan selama tiga tahun berturut-turut terhadap perusahaan non keuangan yang diaudit oleh Kantor Akuntan Publik. Laporan Keuangan Audited biasanya menyertakan catatan-catatan kebijaksanaan yang diambil perusahaan untuk semua akun yang disajikan. Dari Laporan Keuangan Audited tersebut dapat diketahui kegiatan operasional perusahaan termasuk kegiatan yang berhubungan dengan Lingkungan Alam.

\section{HASIL DAN PEMBAHASAN}

\section{Tahapan Perlakuan Alokasi Biaya Lingkungan}

Perusahaan harus melakukan beberapa tahap dalam membuat alokasi biaya lingkungan, menghitung biaya yang akan digunakan dalam pengolahan limbah, pencemaran yang terjadi baik air, udara dan tanah, efek sosial yang terjadi di masyarakat. Tahapan tersebut adalah sebagai berikut: (1) Identifikasi, perusahaan harus mengidentifikasi kegiatan yang akan mengakibatkan pengrusakan lingkungan, pencemaran dan limbah sisa hasil produksi pabrik. Dampak negatif yang terjadi ini harus 
diidentifikasi. (2) Pengakuan, elemen-elemen yang sudah diidentifikasikan selanjutnya diakui sebagai rekening dan disebut biaya pada saat menerima manfaat. Perusahaan mengakui biaya pengelolaan lingkungan alam pada saat transaksi tersebut diterima atau dibayarkan. (3) Pengukuran, perusahaan akan mengukur biaya yang telah dikeluarkan sesuai dengan kondisi riil dan besarnya biaya yang terjadi di periode sebelumnya. Tiap perusahaan mempunyai besaran ukuran yang berbeda dalam alokasi biaya pengolahan lingkungan alam. (4) Penyajian, biaya yang terjadi disajikan dalam akun khusus atau ikut dalam sub-biaya administrasi dan umum. Terkadang pabrikan memasukkan akun biaya ini ke dalam Overhead. Nama akun dapat berbeda-beda di tiap perusahaan karena belum ada standar baku untuk nama akun. Hal yang benar adalah perusahaan mempunyai akun khusus untuk pos biaya lingkungan dan biaya ini dapat dilaporkan tersendiri sehingga muncul pertanggungjawaban sosial ke masyarakat.

\section{Identifikasi}

Identifikasi dilakukan terhadap perusahaan yang mempunyai peranan dalam pengrusakan lingkungan seperti industri yang dijelaskan di atas. Laporan Keuangan diperiksa apakah perusahaan menyebutkan proses produksi yang melibatkan pengrusakan lingkungan, misalnya dalam perusahaan pertambangan, perusahaan mengebor perut bumi sehingga terjadi kerusakan pada bumi. Kemudian penulis melihat apakah perusahaan menyebutkan kepedulian terhadap kerusakan lingkungan yang diakibatkan oleh proses produksinya di catatan kebijaksanaan akuntansi. Yang terakhir dari proses identifikasi ini, Laporan Keuangan dan catatan kebijaksanaan akuntansi diselidiki apakah perusahaan berusaha mengurangi kerusakan lingkungan yang diakibatkan dari proses produksinya.

\section{Pengakuan}

Pada tahap pengakuan, penulis melihat jenis akun yang ada di Laporan Keuangan dan catatan kebijaksanaan akuntansi apakah perusahaan sudah mempunyai rekening khusus yang berkaitan dengan pengerusakan lingkungan alam. Misalnya biaya restorasi alam, biaya penanaman pohon kembali atas tanah yang dikerjakan.

\section{Pengukuran}

Pada tahap pengukuran, perusahaan telah mempunyai anggaran rutin untuk pengelolaan lingkungannya. Biasanya perusahaan yang tidak mengakui biaya pengrusakan lingkungan tidak akan mempunyai pengakuan dan anggaran tiap tahunnya.

\section{Penyajian}

Apabila perusahaan mengakui, mengukur biaya yang berkaitan dengan lingkungan alam maka perusahaan pasti menyajikan biaya lingkungan hidup di Laporan Keuangan dan Catatan Kebijaksanaan Akuntansi. Sampel diambil atas perusahaan yang proses produksinya berpotensi menghasilkan limbah seperti yang disebutkan di atas. Perusahaan yang dimaksudkan adalah perusahaan non-keuangan yang terdaftar di Bursa Efek Indonesia atas Laporan Keuangan yang diaudit untuk periode tahun 2011 sampai dengan tahun 2013. Pengecekan atas akun-akun yang ada di Balance Sheet, Laporan Laba Rugi, Laporan Arus Kas dan Catatan-catatan atas kebijaksanaan akuntansi yang ada di Laporan Audit. Pengecekan atas akun-akun yang berkaitan dengan biaya lingkungan alam dilakukan dengan tujuan apakah perusahaan telah membuat alokasi biaya yang berhubungan dengan lingkungan alam misalnya biaya pengolahan limbah, sampah, restorasi alam dll. 
Tabel 1 Pengecekan Akun-Akun yang Ada di Balance Sheet

\begin{tabular}{llllllllll}
\hline Jenis Laporan & SMCB & ADRO & UNVR & KLBF & ICBP & CPIN & MBTO & FASW & HOME \\
\hline Neraca & Ada & Tidak & Tidak & Tidak & Tidak & Tidak & Tidak & Tidak & Tidak \\
Laba Rugi & Ada & Tidak & Tidak & Tidak & Tidak & Tidak & Tidak & Tidak & Tidak \\
Arus Kas & Tidak & Tidak & Tidak & Tidak & Tidak & Tidak & Tidak & Tidak & Tidak \\
$\begin{array}{l}\text { Catatan Kebijaksanaan } \\
\text { Akuntansi }\end{array}$ & Ada & Ada & Tidak & Ada & Ada & Tidak & Ada & Tidak & Tidak \\
PROPER & & & & & & & & & \\
\hline
\end{tabular}

Hasil

SMCB = PT Holcim Indonesia Tbk, Perusahaan Semen, ada pencatatan biaya restorasi tanah tambang, provisi restorasi.

ADRO = PT Adaro Indonesia Tbk, Perusahaan Pertambangan, ada pencatatan biaya reklamasi.

UNVR = PT Unilever Indonesia Tbk, Perusahaan Barang Konsumen, tidak ada keterangan

KLBF = PT Kalbe Farma Tbk, Perusahaan Farmasi,ada biaya hubungan masyarakat (CSR)

ICBP = PT Indofood CBP Sukses Makmur Tbk, Perusahaan Makanan dan Minuman, ada biaya tanggung jawab sosial perusahaan dan sumbangan.'

CPIN = PT Charoen Phokphand Indonesia Tbk, Perusahaan Makanan Beku,tidak ada keterangan

MBTO = PT Martina Berto Tbk, Perusahaan Jamu dan Kosmetik, ada biaya untuk hubungan masyarakat.

FASW $=$ PT Fajar Surya Wisesa Tbk, tidak ada keterangan.

HOME = PT Hotel Mandarin Regency Tbk, Hotel, tidak ada keterangan.

Tahap-tahap pelaporan akuntansi seperti yang telah dijelaskan diatas melalui diakuinya sebuah akun/rekening biaya dan mempunyai chart of account number kemudian diungkapkan dan disajikan dalam Laporan Keuangan. Akuntansi Lingkungan sebagai metode untuk mengungkap dan menyajikan perlakuan biaya yang berhubungan dengan pengelolaan lingkungan memerlukan tahapan yang runtut dan terperinci sesuai dengan Standar Akuntansi dan Pernyataan Akuntansi Berlaku Umum.

Identifikasi, anya perusahaan PT Holcim Indonesia Tbk yang telah mengidentifikasi dampakdampak negatif yang dihasilkan dari kegiatan operasional perusahaan. Hal ini tercermin dalam biaya restorasi tanah tambang yang muncul di laporan laba rugi dan Provisi untuk restorasi yang muncul di neraca pada Laporan Audit tahun 2011, 2012 dan 2013.

Pengakuan, hanya perusahaan PT Holcim Indonesia Tbk yang telah membuat pengakuan biaya pengendalian lingkungan alam. Hal ini tercermin dalam biaya restorasi tanah tambang yang muncul di laporan laba rugi dan Provisi untuk restorasi yang muncul di neraca pada Laporan Audit tahun 2011, 2012 dan 2013. Ada keterangan mengenai anggaran lingkungan alam di Catatan Atas Kebijaksanaan Akuntansi di Laporan AuditPT Holcim Indonesia Tbk tahun 2011, 2012 dan 2013.

Pengukuran, hanya perusahaan PT Holcim Indonesia Tbk yang telah membuat pengukuran biaya pengendalian lingkungan alam.Hal ini tercermin dalam biaya restorasi tanah tambang yang muncul di laporan laba rugi dan Provisi untuk restorasi yang muncul di neraca pada Laporan Audit tahun 2011, 2012 dan 2013.

Penyajian, hanya perusahaan PT Holcim Indonesia Tbk yang telah membuat penyajian biaya pengendalian lingkungan alam.Hal ini tercermin dalam biaya restorasi tanah tambang yang muncul di laporan laba rugi dan provisi untuk restorasi yang muncul di neraca pada Laporan Audit tahun 2011,2012 dan 2013. 
Hanya PT Holcim Indonesia Tbk saja yang lengkap mengidentifikasi, mengakui,mengukur dan menyajikan biaya lingkungan alam. Sedangkan perusahaan PT Adaro Indonesia Tbk,PT Kalbe Farma Tbk, PT Indofood CBP Sukses Makmur Tbk, PT Martina Berto Tbk, hanya mempunyai biaya hubungan masyarakat (CSR). Untuk perusahaan yang disebut ini, perusahaan hanya membuat penyajian di Catatan Kebijaksanaan Akuntansi tanpa ada keterangan lebih lanjut/detail. Sedangkan untuk PT Unilever Indonesia Tbk, PT Charoen Phokphand Indonesia Tbk, PT Fajar Surya Wisesa Tbk dan PT Hotel Mandarin Regency Tbk belum ada biaya terkait lingkungan alam secara eksplisit. Untuk perusahaan yang disebut ini, diasumsikan bahwa perusahaan telah membuat alokasi biaya pengolahan lingkungan alam tetapi penyajiannya digabung dengan akun yang lain misalnya digabung dengan biaya administrasi dan umum (General and Administrative Expenses) atau Overhead Expenses. Atau digabung dengan biaya lain-lain di Audit Report sehingga penulis tidak bisa mengetahui perincian lain-lain tersebut.

Tidak ada pengungkapan secara detail kebijaksanaan yang dilakukan perusahaan terhadap alam lingkungan. Tidak ada infomasi jelas dan detail yang dapat ditarik kesimpulan dari Catatan tersebut. Tidak dapat diketahui seberapa aware management atas isu-isu lingkungan hidup, pengerusakan yang dilakukan perusahaan dari hasil industri dan kebijaksanaan yang akan diambil atas dampak negatif ini. Tidak ada ketentuan khusus dari Menteri Lingkungan Hidup atas kewajiban untuk membuat akun khusus terkait lingkungan alam. Sehingga penyajian akun masih bersifat sukarela bukan karena paksaaan.

\section{SIMPULAN}

Seharusnya perusahaan menyajikan secara khusus biaya-biaya yang berkaitan dengan pengolahan limbah dan lingkungan alam karena perusahaan yang diambil sampel merupakan perusahaan yang berpotensi untuk menghasilkan limbah dan merusak alam serta perusahaan tersebut merupakan perusahaan besar di Indonesia. Dengan adanya penyajian khusus terkait lingkungan alam, pembaca report dapat mengetahui besarnya pengukuran yang telah diambil management atas pengelolaan lingkungan alam. Biaya yang dialokasikan ke lingkungan alam merupakan investasi bagi perusahaan, perusahaan akan mendapat manfaat sosial dan ekonomi dalam jangka panjang. Masyarakat akan merasa dihargai sebagai makhluk sosial tertinggi.

Dengan adanya keterangan di Catatan Kebijaksanaan Akuntansi, dapat diketahui awareness dari management atas isu-isu lingkungan hidup. Pembaca report dapat mengetahui seberapa besar tingkat kepedulian perusahaan atas lingkungan alam. Selama penelitian dengan pengecekan Laporan Keuangan Audited, tidak ada perusahaan yang mempunyai akun tersendiri untuk akun lingkungan alam, mungkin semua tergabung dalam biaya lain-lain. Pengungkapan sukarela dari management tidak terjadi karena kecenderungan management dengan sengaja menyimpan informasi yang dapat menurunkan image perusahaan karena dapat menurunkan profit perusahaan di masa yang akan datang.

Informasi yang membuat image perusahaan buruk dapat menurunkan harga saham perusahaan dan mempengaruhi kinerja perusahaan dalam mencetak laba. Implementasi dari pencegahan kerusakan lingkungan alam seharusnya ditangani oleh satu unit setingkat direktur atau dibawah direktur yang intens terhadap perkembangan sustain development. Perusahaan harus membuat external cost yaitu biaya terhadap kerusakan lingkungan yang diakibatkan proses produksi perusahaan.

Alokasi biaya lingkungan diperusahaan secara jangka pendek memang sepertinya merupakan beban dan mengurangi profit perusahaan tetapi jangka panjangnya dapat menjadi penghematan energi, kerusakan lingkungan termonitor dan terkendali, perbaikan lingkungan yang berkesinambungan, produktivitas perusahaan meningkat, citra positif perusahaan ramah lingkungan dan akhirnya dapat 
meningkatkan Laba Per Saham perusahaan. Pemerintah harus membuat peraturan yang mensyaratkan setiap industri membuat rekening khusus biaya pengelolaan lingkungan alam, akun tersebut harus mempunyai chart of account tersendiri, disajikan tersendiri dan ada catatan mengenai kebijaksanaan yang diambil terkait lingkungan. Dengan terbitnya peraturan pemerintah maka perusahaan mempunyai pedoman yang jelas bagaimana menerapkan akuntansi lingkungan.

\section{DAFTAR PUSTAKA}

Akuntansi Kejepangan. (2013, 19 Januari). Peranan Akuntansi Lingkungan Dalam Penanggulangan Kerusakan Lingkungan. Akuntansi Sektor Publik. Diakses 20 April 2014 dari http://japanesebuginese.wordpress.com/2013/01/19/peranan-akuntansi-lingkungan-dalam penanggulangan-kerusakan-lingkungan-2/.

Bozidar,L., Ivanisevic, A (2013, Maret). Assessment Of The Most Significant Impacts of Environment on The Changes in Company Cost Structure. Jurnal Ekonomska Istrazivanja, Volume 26(1): 225-242, ISSN 1331-677X. Diakses 20 April 2014 dari http://eresources.pnri.go.id:2056/docview/1466380868/fulltextPDF?accountid=25704.

Kementerian Lingkungan Hidup (Menlh). (2011). Hasil Penilaian PROPER 2010-2011. Diakses 9 Maret 2013 dari http://www.menlh.go.id/hasil-penilaian-proper-periode-2010-2011/.

Kementerian Lingkungan Hidup (Menlh). (2012). Hasil Penilaian PROPER 2012. Diakses 9 Maret 2013 http://www.menlh.go.id/DATA/PROPER2012.PDF.

Laporan Keuangan Perusahaan 2010-2013. Diakses 9 Maret 2013 dari http://www.idx.co.id.

Surat Keputusan Menteri Lingkungan Hidup No 349/Tahun 2013 tentang Hasil Penilaian Peringkat Kinerja Perusahaan Dalam Pengelolaan Lingkungan Hidup Tahun 2012-2013. Diakses 9 Maret 2013 dari: http://proper.menlh.go.id/portal/filebox/131210071728Salinan\%20SK\%20MENLH\%20No. \%20349\%20Tentang\%20Hasil\%20Penilaian\%20PROPER\%202013.pdf. 